\section{Utilization of the field experiment results of University of Debrecen in the development of maize-based bio-ethanol production}

Rátonyi Tamás - Nagy János - Harsányi Endre

Debreceni Egyetem Agrár- és Gazdálkodástudományok Centruma, Mezőgazdaság-, Élelmiszertudományi és Környezetgazdálkodási Kar, Földhasznosítási, Műszaki és Területfejlesztési Intézet, Debrecen ratonyi@agr.unideb.hu

\section{SUMMARY}

Maize is currently the single raw material of bio-ethanol production in Hungary. The aim of our examinations is the observation of yield and nutritional characteristics of commercial maize hybrids in Hungary from the aspect of efficient bio-ethanol production. We set up a randomized block field trial. We determined the starch content and starch yield $\left(t \mathrm{ha}^{-1}\right.$ ) of the 51 maize hybrids involved in the field trial. In laboratory conditions, we examined the amylose and amylopectin ratio and the amount of resistant starch of the selected 20 maize hybrids.

According to our results, there is a significant difference between the starch yield the amylose component of the starch content and resistant starch of the examined maize hybrids. Our studies reveal that maize as a raw material must be selected based on the cultivation objectives. If the objective is bio-ethanol production, detailed knowledge of starch content is necessary. There is a significant difference among commercial maize hybrids in Hungary in terms of characteristics determining the producible amount of bio-ethanol.

Keywords: maize hybrid, starch content, starch yield, resistant starch, bio-ethanol

\section{INTRODUCTION}

Maize is currently the single starting material of bio-ethanol production in Hungary. The cultivation conditions of Hungary are perfect for maize production, maize is grown on the quarter of cultivable land (1.2 million ha). Most of the current research is aimed towards improving the efficiency of maize-based bioethanol production. Conversion efficiency to produce ethanol by fermentation is usually $90-95 \%$. The reasons for the imperfect conversion efficiency may include incomplete hydrolyses of starches (Wu et al., 2006). The most important measure of value of maize-based bio-ethanol production is starch content and starch yield of the raw material. Amylose and amylopectin represent 98 to $99 \%$ starch dry weight in maize kernel (Sharma et al., 2010). The ratio of amylose/amylopectin is essentially important, because it determines the gelificiation characteristics within the process of saccharification. In the course of production, alphaamylase and amyloglucosidase enzymes are used in most cases; therefore it is important to know the content of starch resistant to alpha-amylase.

\section{MATERIAL AND METHODS}

The objective of this study was to characterise maize starch content for bio-ethanol production purpose. We set up random block layout maize field experiment at the Field Experimental Station of the Centre for Agricultural and Applied Economic Sciences, Debrecen University located in the north-eastern part of the Great

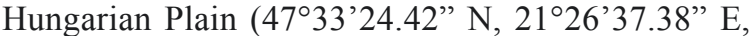
$121 \mathrm{~m}$ elevation). The soil of the experimental site is lowland pseudomyceliar chernozem (Mollisol-Calciustoll or Vermustoll, silt loam). The climate is temperate continental, with an annual precipitation of $518 \mathrm{~mm}$ in 2011 of which $62.5 \%$ (324 mm) occurs during the growing season (from April to September).

51 maize hybrids chosen for bio-ethanol production were set up in the experiment hybrids (APPLYGEN Ply29; APPLYGEN Ply35; Debrecen 285 Debreceni 377 Debreceni 382 DKC 3707; DKC 4082; DKC 4490; DKC 4590; DKC 4608; DKC 4795; DKC 4995; DKC 5007; DKC 5276; DKC EH 3605; EURALIS Flato; EURALIS Sensor; EURALIS Zodiac; GK Boglár; GK Kenéz; GK Sarolta; KWS 2376; KWS Kamelias; KWS Kessos; KWS Kinemas; KWS Koral; KWS Kornélia; KWS Krabas; Lg LZM-457/43; MV 255; MV 343; MV 350; MV 500; MV Koppány; Pioneer 9494; Pioneer 9578; RAGT Alexxandra; RAGT Alexxandra duo; RAGT Duboxx; RAGT Luxxus; RAGT Oxxygen; RAGT Phileaxx; RAGT Poluxx; RAGT RH07103; RAGT RH09110; RAGT Roxxy; RAGT Rulexx; RAGT Texxel; SATEN Union Sumbra; Syngenta Syondia; Szegedi 386). Starch content (g $\left.100 \mathrm{~g}^{-1}\right)$ and starch yield $\left(\mathrm{t} \mathrm{ha}^{-1}\right)$ of maize hybrids were investigated in 2011. Maize grain samples were collected before harvest.

The laboratory examinations of maize grain samples were done at the Institute of Land Utilisation, Technology and Regional Development, Centre for Agricultural and Applies Economic Sciences, Debrecen University. After sample preparation starch content of maize hybrids were evaluated by Foss InfratecTM 1241 Grain Analyzer. The measurements are based on the fact that the main components in the grain (maize), such as protein, moisture, starch, fat, absorb electromagnetic radiation in the near-infrared region of the spectrum $(570-1100 \mathrm{~nm})$. The Near Infrared Transmission (NIT) instrument measures the transmission absorption, the main components of whole maize grain samples are determined by calibration curves, the accuracy of prediction could be comparable to chemical methods (Wei et al., 2005).

Amylose/amylopectin ration and resistant starch (\%) content of 20 maize hybrids were determined in the laboratory. Amylose/amylopectin ratio and resistance starch of the maize starch content were determined according to the protocol of Megazyme International Ireland Ltd. Maize starch was solubilized in water by dimethyl-sulfoxide (DMSO). Concanavalin A precipitation of amylopectin was carried out. 
Then the amylose determined by glucose-oxidase enzyme after treatment with $\alpha$-amylase and amyloglucosidase. The absorbance of created glucose from amylose was detected at $510 \mathrm{~nm}$. To determine of resistant starch firstly we solubilized and hydrolized the non-resistant starch with enzymes ( $\alpha$-amylase and amyloglucosidase). Then the starch resistant to $\alpha$-amylase exist as pellet. This pellet were solubilized by 2 mol potassium-hydroxide on ice, the next steps were the neutralization and the hydrolization. The resulting glucose was defined by glucose-oxidase enzyme at $510 \mathrm{~nm}$. Statistical analysis package of SPSS 14.0 for Windows statistical software was used.

\section{RESULT AND DISCUSSIONS}

\section{Starch content of the maize hybrids}

The kernel of maize (Zea mays L.) is mainly composed of starch. The starch content is genetically determined parameter varied between very narrow ranges. Researchers were concluded that ethanol production of maize is not exclusively dependent on starch content and that the chemical structure of starch (Dien et al., 2002; Sing et al., 2005). Starch content of the kernel alone cannot predict the ethanol production of maize.

The average starch content in dry matter $\%$ of the kernels of the maize hybrid in the experiment was $71.96 \%$. We measured a $4.51 \%$ difference between the maize hybrids with the highest (74.34\%) and the lowest (69.82\%) starch content (Figure 1).

Figure 1: Starch content $\left(\mathbf{g} \mathbf{1 0 0 ~ \mathbf { g } ^ { - 1 } )}\right.$ of the investigated maize hybrids (Debrecen, 2011)

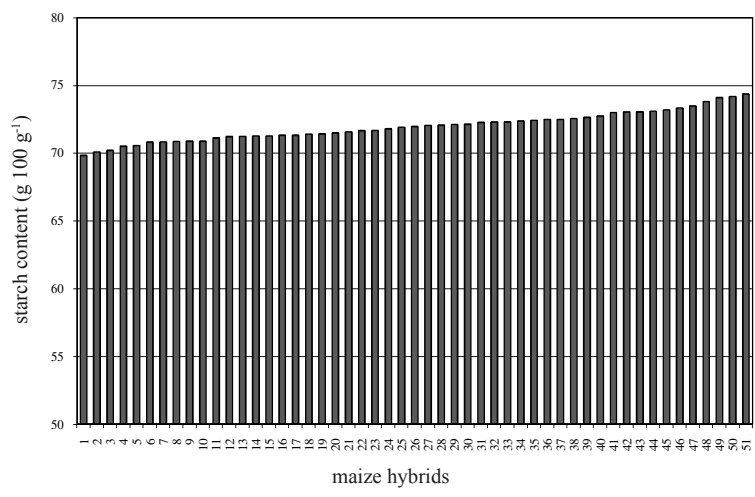

Significant difference can be found between the starch content of the examined maize hybrids. The analysed hybrids were ranked by their starch content: very high starch (>73\%; DKC 4795; DKC 4590, DKC EH 3605; DKC 4490, MV 255, DKC 4082), high starch content $(71-73 \%)$, medium starch content $(70-71 \%)$ and low starch content $(<70 \%)$.

\section{Starch yield of the maize hybrids}

Starch yield $\left(\mathrm{t} \mathrm{ha}^{-1}\right)$ was calculated from the starch content $(\%)$ and the yield $\left(\mathrm{t} \mathrm{ha}^{-1}\right)$ of the maize hybrids. The average starch yield of the maize hybrid in the experiment was $7.06 \mathrm{tha}^{-1}$. We measured a $3.02 \mathrm{tha}^{-1}$ difference between the maize hybrids with the highest $\left(8.36 \mathrm{t} \mathrm{ha}^{-1}\right)$ and the lowest $\left(5.34 \mathrm{t} \mathrm{ha}^{-1}\right)$ starch yield (Figure 2).
Figure 2: Starch yield $\left(\mathbf{t ~ h a}^{-1}\right)$ of the investigated maize hybrids (Debrecen, 2011)

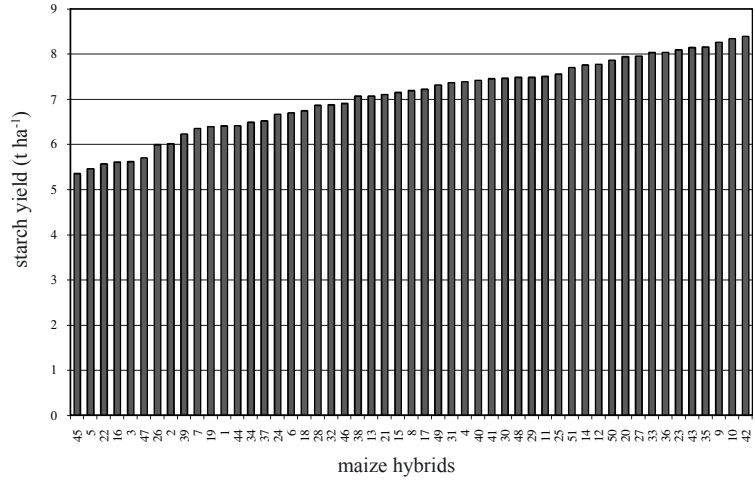

Significant difference can be found between the starch yields of the examined maize hybrids. The analysed hybrids were ranked by their starch yield: very high starch yield $\left(>8 \mathrm{t} \mathrm{ha}^{-1}\right.$, RAGT Phileax, SATEN Union Sumbra, LG LZM-457/43, DKC 5276, DKC 4608, DKC 4995), high starch yield (7-8 $\left.\mathrm{t} \mathrm{ha}^{-1}\right)$, medium starch yield $\left(6-7 \mathrm{tha}^{-1}\right)$ and low starch yield $\left(<6 \mathrm{tha}^{-1}\right)$

\section{Amylose ratio in starch of the maize kernels}

Starch in maize kernels can be separated into two fractions: amylose and amylopectin. Maize hybrids differ for amylose to amylopectin ratios. Amylose content has a significant effect on ethanol fermentation efficiency. Amylose content negatively correlated to bioethanol concentrations from starch, conversion efficiency decrease as the amylose content increased, however authors concluded that there was no significant effects on fermentation efficiency when amylose content was less than 30\% (Wu et al., 2006; Sharma et al., 2010).

Amylose making up 12.2-30.71\%, the component, amylopectin makes up $69.29-87.8 \%$ of the starch content of the investigated maize hybrids (Figure 3). The difference amongst the amylose content of the maize hybrids was significant; we found twofold differences between the maize hybrids.

Figure 3: Amylose ratio in starch of the maize kernels (Debrecen, 2011)

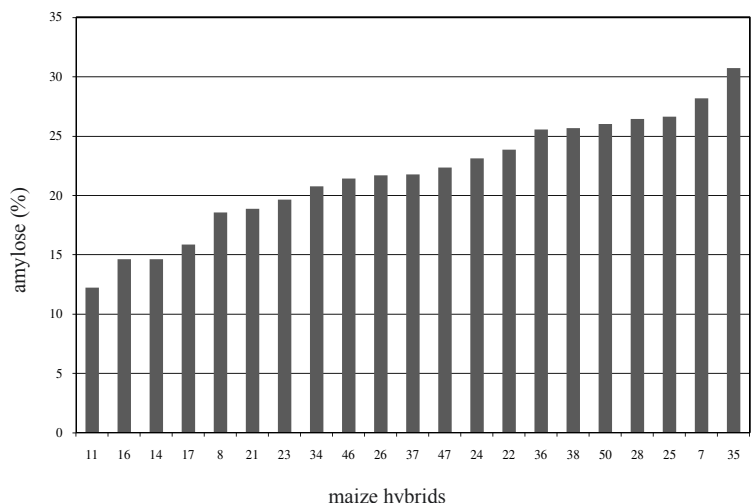

\section{Resistant starch in maize kernels}

Starch which is resistant to enzymatic hydrolysis process is called resistant starch. Higher initial resistant 
starch resulted in lower conversion of starch into sugars and lower final ethanol production (Sharma et al., 2010).

The amount of resistant starch is depends on the genotypes of raw material. Significant difference can be found between the resistant starch content of the examined maize hybrids. The average resistant starch content of the maize kernels of the maize hybrid in the experiment was $4.06 \%$. We measured a $5.93 \%$ difference between the maize hybrids with the highest $(8.03 \%)$ and the lowest $(2.1 \%)$ resistant starch content (Figure 4). Differences amongst resistant starch of maize kernels reach fourfold value.

Figure 4: Resistant starch content in starch of the maize kernels (Debrecen, 2011)

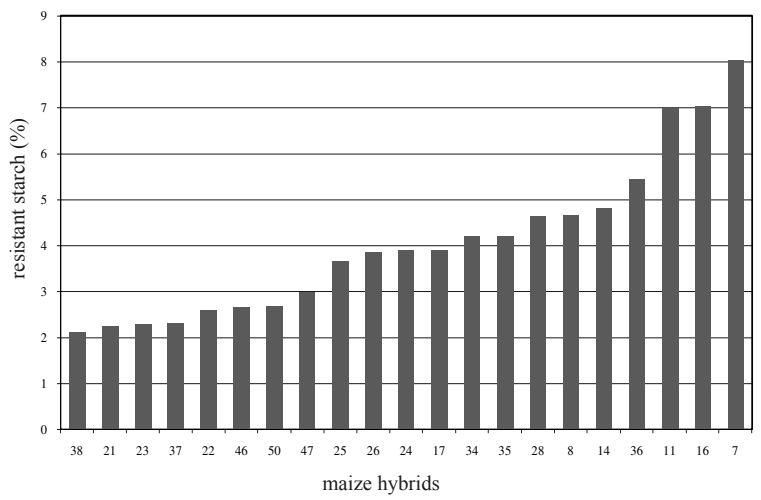

\section{Correlation analysis}

Relationship between starch content and the amylose content and between starch content and resistant starch content in the kernels of the investigated maize hybrids could not be found. The amount of starch content did not influence the amount of amylose and resistant starch. Total starch content had a weak correlation $\left(\mathrm{R}^{2}=\right.$ 0.11 and 0.08 ) with amylose content and resistant starch.

The amylose content and resistant starch content had a moderate negative correlation $\left(\mathrm{R}^{2}=0.51\right)$. Resistant starch contents decrease as the amylose content in starch increases (Figure 5).
Figure 5: Correlation between amylose and resistant starch of the investigated maize hybrids

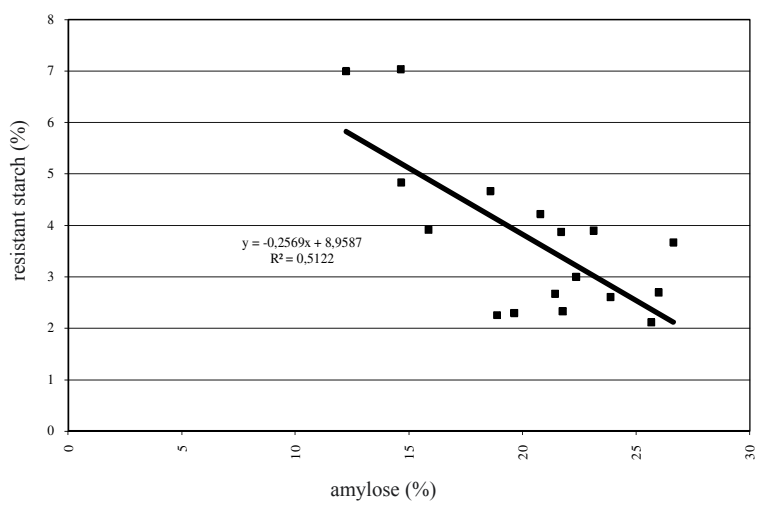

\section{CONCLUSIONS}

Our studies reveal that maize as a raw material of bio-ethanol production shall be selected based on the cultivation objectives. If the objective is bio-ethanol production detailed knowledge of starch content, starch yield, amylose/amylopectin ratio and resistant starch content are necessary. There is a significant difference among commercial maize hybrids in Hungary in terms of characteristics determining the producible amount of bio-ethanol. Significant difference can be found between the starch content, starch yield, amylose ratio and resistant starch of the examined maize hybrids. Starch content of the maize had a weak correlation with amylose content and resistant starch. Moderate negative correlation can be found between amylose content and resistant starch, as the amylose content in the starch increase in the maize kernels the resistant starch content decrease.

\section{ACKNOWLEDGEMENTS}

The publication is supported by projects NKTH TECH-09-A3-2009-0227, BIOKONV9, project no. OM-00210/2008 of the Research and Technology Fund, projects FP7-REGPOT-2010-1 UD AGR REPO, TÁMOP 4.2.1./ B-09/1/KONV-20 $\overline{10}-000 \overline{7}$ and TÁMOP 4.2.2./B-10/1-2010-0024. The project is financed by the European Union and co-financed by the European Regional Development Fund and the European Social Fund.

\section{REFERENCES}

Dien, B. S.-Bothast, R. J.-Iten, L. B.-Barrios, L.-Eckhoff, S. R. (2002): Fate of Bt protein and influence of corn hybrid on ethanol production. Cereal Chem. 79: 582-585.

Sharma, V.-Rausch, K. D.-Graeber, J.V.-Schmidt, S.J.-Buriak, P.-Tumbleson, M.E.-Singh, V. (2010): Effect of resistant starch on hydrolysis and fermentation of corn starch for ethanol. Appl Biochem Biotechnol. 160. 3: 800-811.

Singh, V.-Graeber, J. V. (2005): Effect of corn hybrid variability and planting location on dry grind ethanol production. Trans. Am. Soc. Agric. Eng. 48: 709-714.
Wei, L. M.-Jiang, H. Y.-Li, J. H.-Yan, Y. L.-Dai, J. R. (2005) Predicting the chemical composition of intact kernels in maize hybrids by near infrared reflectance spectroscopy. National Maize Improvement Center of China, China Agricultural University. Beijing. 100094. China. 25. 9: 1404-7.

Wu, X.-Zhao, R.-Wang, D.-Bean, S. R.-Seib, P. A.-Tuinstra, M. R.-Campbell, M.-O'Brien, A. (2006): Effects of amylose, corn protein, and corn fiber contents on production of ethanol from starch-rich media. Cereal Chem. 83: 569-575. 
